\title{
Cyclic testing of reinforced concrete beam-column joints with crossed inclined bars
}

\author{
C. E. Chalioris, C. G. Karayannis \& M. I. Favvata \\ Department of Civil Engineering, Democritus University of Thrace, \\ Greece
}

\begin{abstract}
The use of crossed inclined bars in external beam-column connections under cyclic deformations is experimentally investigated. For this purpose, test results of four Reinforced Concrete (RC) joint subassemblages subjected to constantly increasing pseudo-seismic loading are presented. The shear reinforcement in the joint area for two specimens was two pairs of inclined bars that formed a pair of $\mathrm{X}$-type reinforcement. The other two specimens were conventionally reinforced joints (control specimens). The effectiveness of this X-type, non-conventional reinforcement on the overall seismic performance of the tested joints is examined. The beam and the columns of all the specimens were designed according to the requirements of ACI 318-02 and the recommendations of ACI-ASCE 352-02 (Type 2 exterior connections). The design of the joint area for one control specimen was also carried out according the ACI Design Codes and the required amount of steel stirrups (5Ø8) was added in the joint body. The other control specimen had no stirrup at the joint area. Comparisons between the test results of the examined specimens indicated that the cyclic behaviour of the joints with X-bars was ameliorated with respect to the response of the control specimen without stirrups. Further, load capacity and hysteretic energy dissipation values of the joint with $2 \mathrm{X}$-bars $\varnothing 14$ were slightly lower than the values of the control specimen which joint area had stirrups $(5 \varnothing 8)$ according to the specifications of ACI Design Codes.

Keywords: beam-column joint, cyclic tests, reinforced concrete, inclined bars.
\end{abstract}




\section{Introduction}

The behaviour of beam-column joints has long been recognized as a significant factor that frequently becomes critical for the overall behaviour of Reinforced Concrete $(\mathrm{RC})$ framed structures subjected to seismic excitations. The response of $\mathrm{RC}$ connections involves the influence of complex interacting phenomena such as shear, bond, confinement, fatigue, which even independently are not yet well understood [1]. Therefore, experimental research is very often the main method for the investigation of the parameters that influence and improve the joint performance [2]. It is also noted that detailed design recommendations for RC beam-column joints were first published in the last two decades in Europe and in the last three decades in USA.

Attempts at any improvement of the seismic properties of these members are mainly focus on the use of non-conventional reinforcement, such as steel fibres, composite materials (FRPs), inclined bars and spiral reinforcement [3]. The first idea of the use of crossed inclined bars in RC joints was developed in 1984 [4]. Since then, further experimental and analytical studies indicated that joints with $\mathrm{X}$-type reinforcement exhibited improved behaviour in respect to joints with conventional reinforcement [5-8].

The aim of the present work is to experimentally investigate the effectiveness of crossed inclined bars in external beam-column connections subjected to cyclic loading. Four RC joint specimens with different reinforcement arrangements in the joint area, that included X-bars and stirrups, were tested to the same constantly increasing cyclic loading sequence and useful concluding remarks were derived.

\section{Experimental program}

The experimental program of this paper includes 4 external beam-column joint specimens. The geometry of the specimens was the same; total columns height and cross-section dimensions $1800 \mathrm{~mm}$ and $300 \times 200 \mathrm{~mm}$, respectively, whereas beam length and cross-section dimensions were $1300 \mathrm{~mm}$ and 200/300 $\mathrm{mm}$, respectively. The beam and the columns of all the specimens were designed according to the specifications of ACI 318-02 [9] and ACI-ASCE 352-02 [10] for Type 2 exterior connections (see Table 1 and Figure 1). The shear reinforcement of the joint area varied. First, control specimen JA-0 had no stirrups ( 2 vertical $\varnothing 10$ column bars were placed through the joint area as in all the specimens). The joint area of control specimen JA-s5 was designed according the ACI Design Codes and $5 \varnothing 8$ steel stirrups were added (required amount of stirrups). Finally, specimens JA-2X12 and JA-2X14 had two pairs of inclined bars $\varnothing 12$ and $\varnothing 14$, respectively, which formed a pair of X-type reinforcement (Figure 1). Geometry and detailed reinforcement arrangement of the tested specimens are shown in Figure 1 and presented in Table 1. Concrete mean cylinder compressive strength at the age of 28 days was $f_{\mathrm{cm}}=34 \mathrm{MPa}$ and steel yield strength was $580 \mathrm{MPa}$. 
Table 1: Reinforcement arrangement of the beam-column joint specimens.

\begin{tabular}{|c|c|c|c|}
\hline Specimen & Columns & Beam & Joint area \\
\hline JA-0 & $\begin{array}{l}4 \varnothing 14 \text { (corner bars) } \\
(+2 \varnothing 10 \text { middle bars }) \\
\text { Stirrups: } \varnothing 8 / 50 \mathrm{~mm}\end{array}$ & $\begin{array}{c}4 \varnothing 12 \text { top } \\
4 \varnothing 12 \text { bottom } \\
\text { Stir.: } \varnothing 8 / 65 \\
\mathrm{~mm}\end{array}$ & (2Ø10 vertical bars) \\
\hline JA-s5 & $\begin{array}{l}4 \varnothing 14 \text { (corner bars) } \\
(+2 \varnothing 10 \text { middle bars }) \\
\text { Stirrups: } \varnothing 8 / 50 \mathrm{~mm}\end{array}$ & $\begin{array}{c}4 \varnothing 12 \text { top } \\
4 \varnothing 12 \text { bottom } \\
\text { Stir.: } \varnothing 8 / 65 \\
\mathrm{~mm}\end{array}$ & $\begin{array}{c}5 \varnothing 8(\varnothing 8 / 50 \mathrm{~mm}) \\
(+2 \varnothing 10 \text { vertical bars })\end{array}$ \\
\hline JA-2X12 & $\begin{array}{c}4 \varnothing 14(+4 \varnothing 12)^{*} \text { (corner) } \\
(+2 \varnothing 10 \text { middle bars }) \\
\text { Stirrups: } \varnothing 8 / 50 \mathrm{~mm}\end{array}$ & $\begin{array}{c}4 \varnothing 12 \text { top } \\
4 \varnothing 12 \text { bottom } \\
\text { Stir.: } \varnothing 8 / 65 \\
\mathrm{~mm}\end{array}$ & $\begin{array}{c}2 \mathrm{X} \varnothing 12 \\
(+2 \varnothing 10 \text { vertical bars })\end{array}$ \\
\hline JA-2X14 & $\begin{array}{c}4 \varnothing 14(+4 \varnothing 14)^{*} \text { (corner) } \\
(+2 \varnothing 10 \text { middle bars }) \\
\text { Stirrups: } \varnothing 8 / 50 \mathrm{~mm}\end{array}$ & $\begin{array}{c}4 \varnothing 12 \text { top } \\
4 \varnothing 12 \text { bottom } \\
\text { Stir.: } \varnothing 8 / 65 \\
\mathrm{~mm}\end{array}$ & $\begin{array}{c}2 \mathrm{X} \varnothing 14 \\
(+2 \varnothing 10 \text { vertical bars })\end{array}$ \\
\hline
\end{tabular}

The inclined X-bars in joint area were extended to the entire height of both columns.

Test setup and instrumentation details are shown in Figure 2. Supports that allow rotation were used to simulate the inflection points assumed to occur at a point of the columns in a laterally-loaded frame structure. Column axial load with value equal to $\mathrm{N}_{\mathrm{c}}=0.05 \times \mathrm{A}_{\mathrm{c}} \times f_{\mathrm{cm}}$ was applied during the tests. All specimens were subjected to full cycle deformations imposed near the free end of the beam by a pinned-end actuator. The moment arm for the applied load was equal to 1.2 m.

Tested specimens were suffered a loading history of five full loading steps with maximum displacements $\pm 6 \mathrm{~mm}, \pm 20 \mathrm{~mm}, \pm 40 \mathrm{~mm}, \pm 60 \mathrm{~mm}$ and \pm 80 $\mathrm{mm}$ at each step. Every loading step included two full load cycles, thus, the loading sequence was performed the way it is shown in Figure 3.

The imposed load was measured by a load cell with accuracy equal to 0.025 $\mathrm{kN}$ and the displacements of the beam were measured by linear variable differential transducer (LVDT) with accuracy equal to $0.01 \mathrm{~mm}$.

\section{Test results}

The hysteretic responses of the tested specimens are compared in Figures 4 and 5. Further, the values of the maximum bending moment (load capacity) and the hysteretic energy dissipation in terms of the area of the response loading cycle for each loading cycle and for each joint are presented in Table 2. 


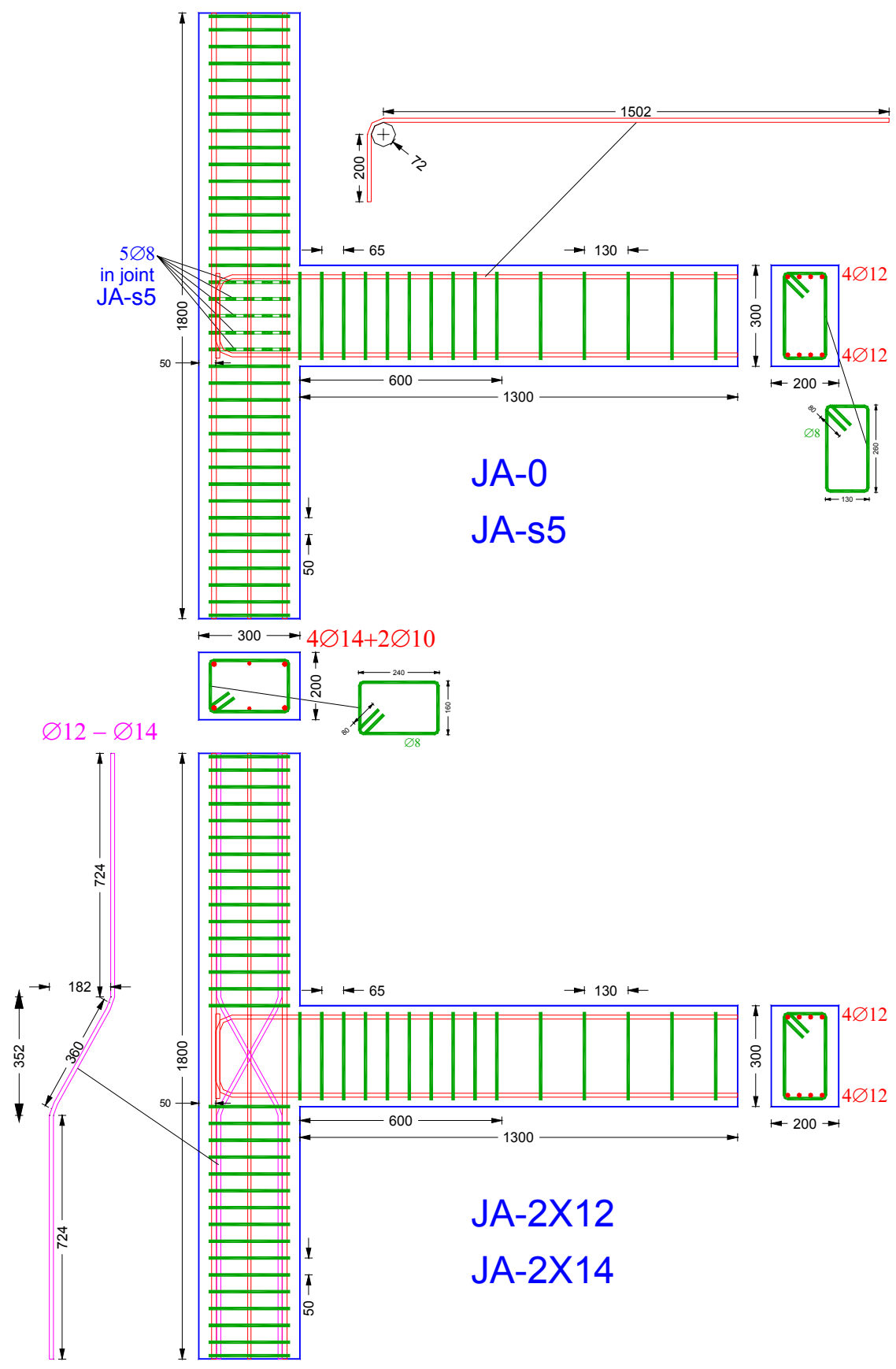

Figure 1: Geometry and reinforcement arrangements of the tested specimens. 


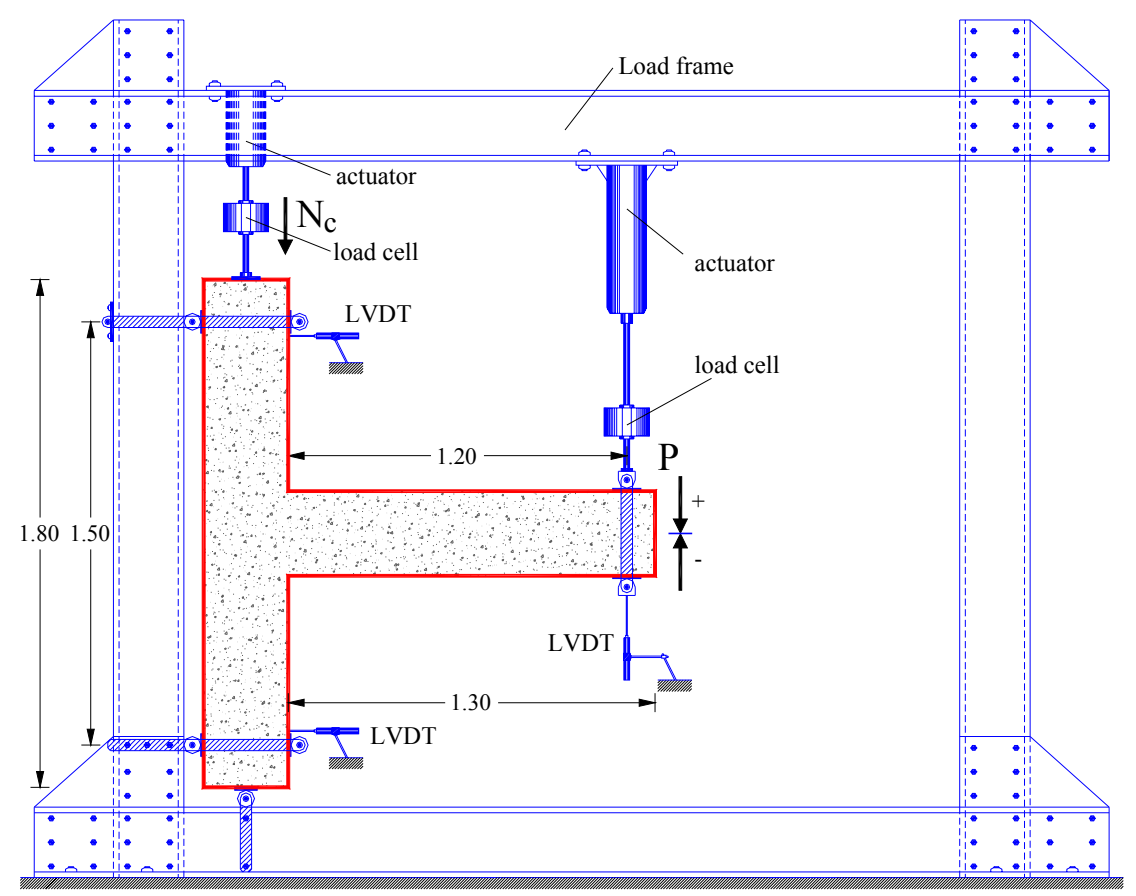

Figure 2: $\quad$ Test setup.

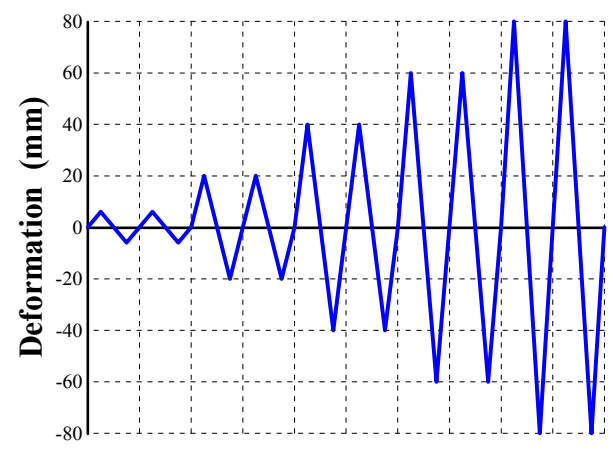

Figure 3: Loading history.

In order to evaluate the effectiveness of the examined reinforcement in the joint area, the final cracking patterns of the tested joints are illustrated in the photos of Figure 6 . Based on the damage modes and the observations of cracking propagation during the entire cyclic loading procedure of the specimens, it is deduced that crossed inclined bars inhibited the damage in the joint area and considerably improved the damage mode characteristics (distinct plastic hinges were formed). Further, the presence of stirrups (specimen JA-s5) proved to be 
628 Computational Methods and Experimental Measurements XIII

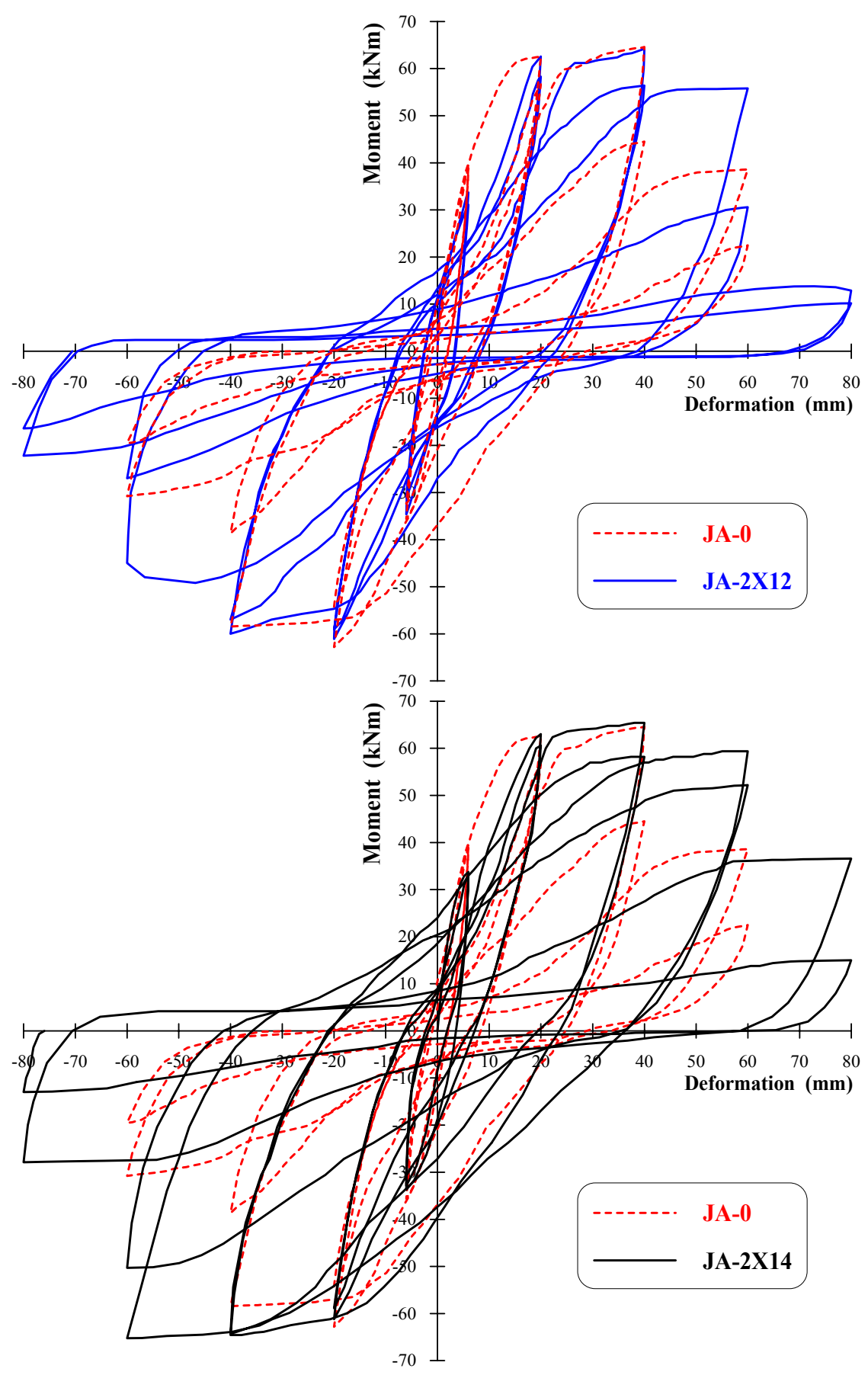

Figure 4: Comparison of the hysteretic responses of the tested specimens.

WIT Transactions on Modelling and Simulation, Vol 46, (C) 2007 WIT Press

www.witpress.com, ISSN 1743-355X (on-line) 


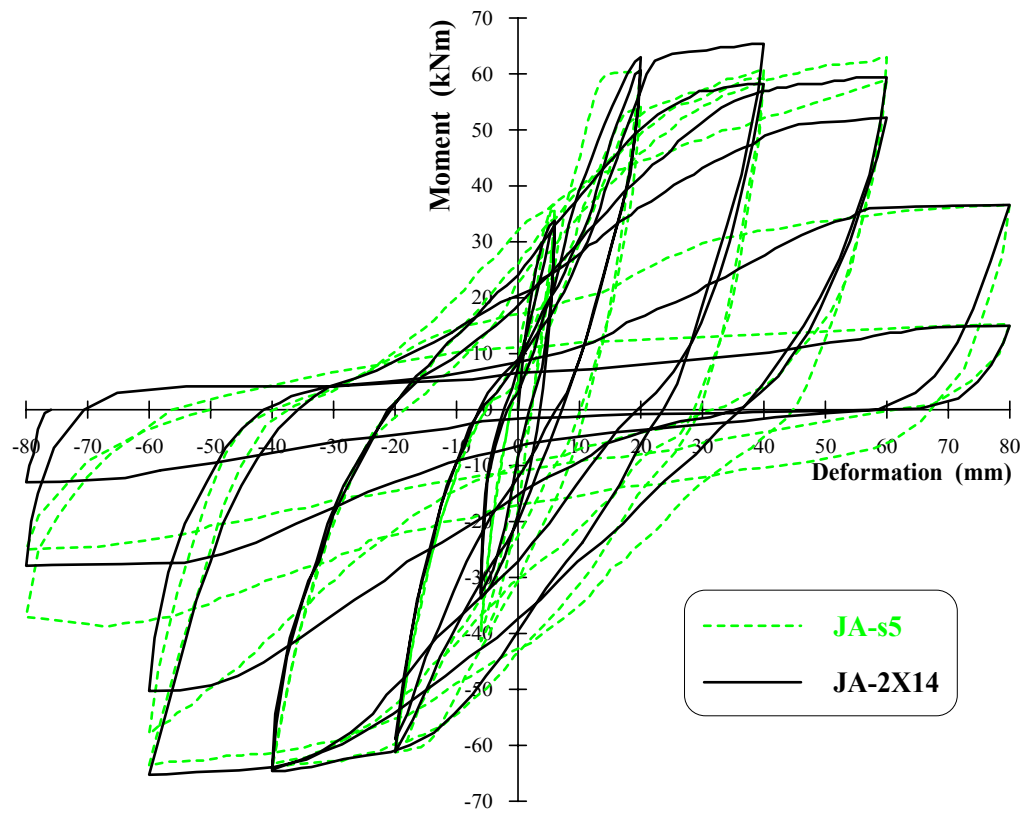

Figure 5: Comparison of the hysteretic responses of joints JA-s5 and JA2X14.

Table 2: $\quad$ Test results.

\begin{tabular}{|c|c|c|c|c|c|c|c|c|}
\hline \multirow[b]{2}{*}{ Cycle } & \multicolumn{2}{|c|}{ JA-0 } & \multicolumn{2}{|c|}{ JA-s5 } & \multicolumn{2}{|c|}{ JA-2X12 } & \multicolumn{2}{|c|}{ JA-2X14 } \\
\hline & $\underset{(k N \cdot m)}{\text { Moment }}$ & $\begin{array}{l}\text { Energy } \\
(\mathrm{kN} \cdot \mathrm{m} \cdot \mathrm{mm})\end{array}$ & $\begin{array}{c}\text { Moment } \\
(\mathrm{kN} \cdot \mathrm{m})\end{array}$ & $\begin{array}{c}\text { Energy } \\
(\mathrm{kN} \cdot \mathrm{m} \cdot \mathrm{mm})\end{array}$ & $\underset{(k N \cdot m)}{\text { Moment }}$ & $\left|\begin{array}{c}\text { Energy } \\
(\mathrm{kN} \cdot \mathrm{m} \cdot \mathrm{mm})\end{array}\right|$ & $\begin{array}{c}\text { Moment } \\
(\mathrm{kN} \cdot \mathrm{m})\end{array}$ & $\begin{array}{l}\text { Energy } \\
(\mathrm{kN} \cdot \mathrm{m} \cdot \mathrm{mm})\end{array}$ \\
\hline $6-1+$ & 39.8 & \multirow{2}{*}{178.1} & 36.7 & \multirow{2}{*}{215.2} & \begin{tabular}{|l|}
33.7 \\
\end{tabular} & \multirow{2}{*}{206.7} & 33.8 & \multirow{2}{*}{275.5} \\
\hline 6-1- & -35.6 & & -41.4 & & -34.6 & & -33.8 & \\
\hline $6-2+$ & 38.9 & \multirow{2}{*}{149.4} & 35.7 & \multirow{2}{*}{158.1} & 31.1 & \multirow{2}{*}{227.8} & 33.1 & \multirow{2}{*}{196.3} \\
\hline $6-2-$ & -32.4 & & -38.7 & & -31.1 & & -32.9 & \\
\hline $20-1+$ & 62.6 & \multirow{2}{*}{1267.8} & 60.4 & \multirow{2}{*}{1405.2} & 62.6 & \multirow{2}{*}{985.9} & 63.0 & \multirow{2}{*}{969.1} \\
\hline $20-1-$ & -62.8 & & -61.2 & & -61.1 & & -61.2 & \\
\hline $20-2+$ & 56.7 & \multirow{2}{*}{535.3} & 54.2 & \multirow{2}{*}{1095.3} & 58.3 & \multirow{2}{*}{885.6} & 60.6 & \multirow{2}{*}{767.3} \\
\hline $20-2-$ & -54.2 & & -60.0 & & -59.0 & & -58.9 & \\
\hline $40-1+$ & 64.6 & \multirow{2}{*}{3454.6} & 60.9 & \multirow{2}{*}{4013.4} & 64.2 & \multirow{2}{*}{3207.2} & 65.4 & \multirow{2}{*}{3817.6} \\
\hline $40-1-$ & -58.5 & & -64.2 & & -60.0 & & -64.6 & \\
\hline $40-2+$ & 44.5 & \multirow{2}{*}{1454.4} & 59.2 & \multirow{2}{*}{3917.2} & 56.4 & \multirow{2}{*}{2625.9} & 58.2 & \multirow{2}{*}{3479.9} \\
\hline 40-2- & -38.7 & & -63.3 & & -57.0 & & -64.3 & \\
\hline $60-1+$ & 38.6 & \multirow{2}{*}{2164.8} & 63.0 & \multirow{2}{*}{6644.7} & 55.8 & \multirow{2}{*}{4385.0} & 59.4 & \multirow{2}{*}{5975.9} \\
\hline $60-1-$ & -30.8 & & -63.6 & & -49.2 & & -65.3 & \\
\hline $60-2+$ & 22.5 & \multirow{2}{*}{899.4} & 59.0 & 46133 & 30.6 & 21436 & 52.2 & 44177 \\
\hline 60-2- & -19.6 & & -58.0 & 4013.3 & -27.0 & 2143.0 & -50.3 & $441 / .1$ \\
\hline $80-1+$ & - & & 36.7 & & 13.8 & & 36.6 & \\
\hline $80-1-$ & - & $\begin{array}{l}- \\
-1\end{array}$ & -38.8 & 5414.0 & -22.2 & 1915.5 & -27.9 & 3094.5 \\
\hline $80-2+$ & - & & 15.3 & 29753 & 10.2 & 12025 & 15.0 & 17317 \\
\hline $80-2-$ & - & $\begin{array}{l}- \\
-\end{array}$ & -25.0 & 2915.3 & -16.4 & 1202.3 & -13.0 & \\
\hline
\end{tabular}



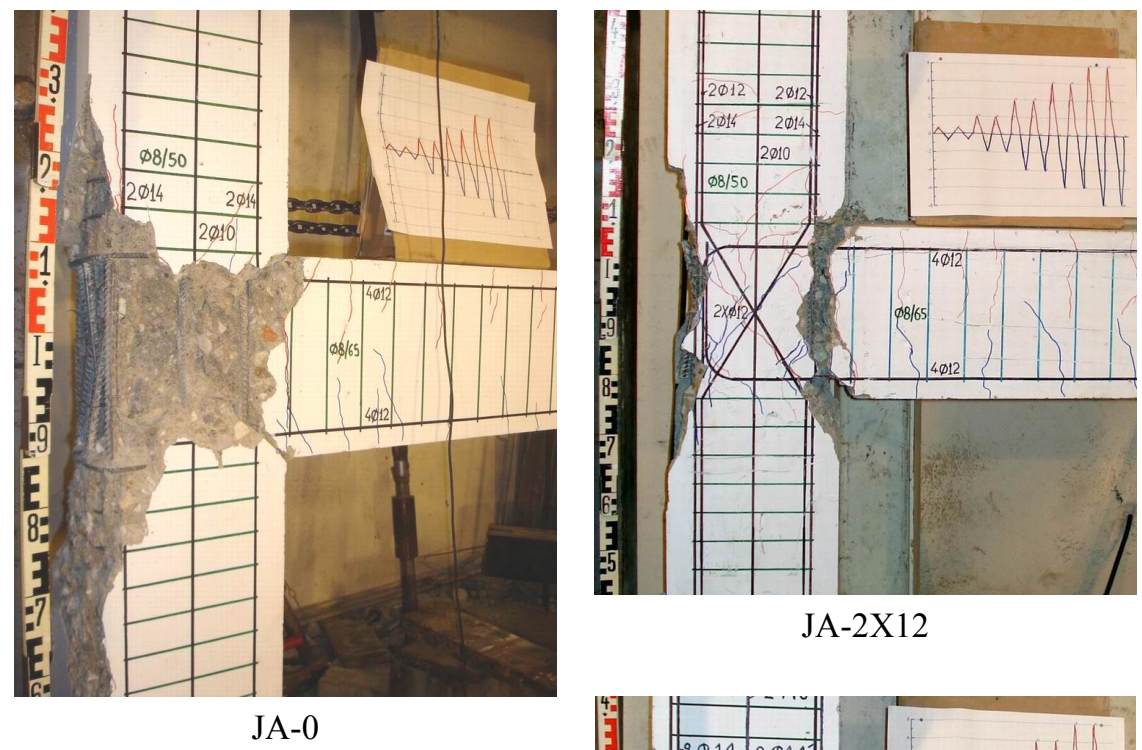

JA-2X12

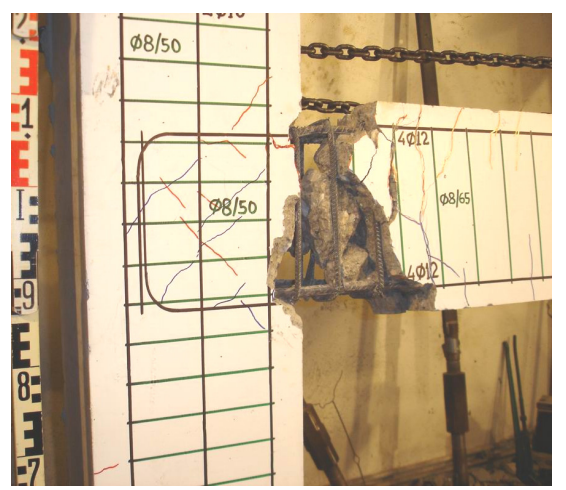

JA-s5

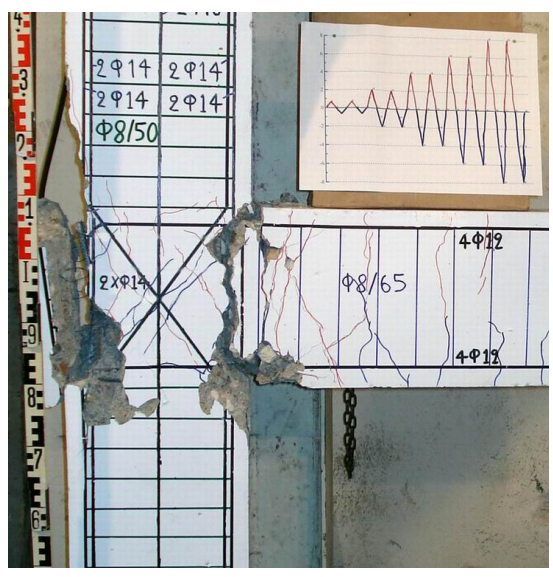

JA-2X14

Figure 6: Damage modes and crack patterns at the end of the loading sequence.

essential since stirrups increased the joint shear capacity and restrained the deformations of the bend anchorage of the beam's bars that caused severe damages at the back of the joint area in the other specimens without stirrups.

\section{Concluding remarks}

Cyclic test results of four RC external beam-column joint specimens were presented herein, in order to investigate the effectiveness of crossed inclined bars as shear reinforcement in joint area. The specimens were designed according the specifications of ACI 318-02 and ACI-ASCE 352-02. Based on the hysteretic 
responses and the cracking modes of the tested joints it is deduced that the overall seismic performance of the joints with X-type reinforcement was considerably improved with respect to the response of the control specimen without stirrups. Joints with X-bars, in comparison with the control specimen without stirrups, exhibited higher values of load capacity in most of the loading cycles and increased hysteretic energy dissipation practically in the entire loading sequence. This improvement was greater in the higher deformation loading cycles. Further, the hysteretic response of the specimen with $2 \mathrm{X} \varnothing 14$ as shear reinforcement in joint area was slightly lower from the response of the control specimen with $5 \varnothing 8$ stirrups, which followed the guidelines of ACI Design Codes. Concerning the cracking patterns, the deformations of the bend anchorage of the beam's bars (anchorage failure) in combination with the absence of stirrups in the joint area contributed to significant damage of the concrete cover at the back of the joint area. Stirrups restrained these deformations and kept the joint body quite intact. Specimens with X-bars performed enhanced damage mode since distinct flexural hinge was developed in the beam-joint interface.

\section{References}

[1] Karayannis, C.G. \& Sirkelis, G.M., Effectiveness of RC beam-column connections strengthening using carbon-FRP jackets, Proc. of the 12th European Conference on Earthquake Engineering, London, UK, PR 549, 2002.

[2] Karayannis, C.G., Sirkelis, G.M. \& Chalioris, C.E., Seismic performance of RC beam-column joints retrofitted using light RC jacket - Experimental study, Proc. of the 1st European Conference on Earthquake Engineering and Seismology, Geneva, Switzerland, PN.136, 2006.

[3] Karayannis, C.G. \& Sirkelis, G.M., Response of columns and joints with spiral shear reinforcement, Proc. of the 12th Int. Conference: Computational Methods and Experimental Measurements (CMEM), Malta, Wessex Institute of Technology Transactions on Modelling and Simulation, Vol. 41, 2005.

[4] Paulay, T. \& Park, R., Joints of reinforced concrete frames designed for earthquake resistance. Research report 84-9, Dept. of Civil Engineering, Univ. of Canterbury, Christchurch, New Zealand, 1984.

[5] Tsonos, A.G., Tegos, I.A. \& Penelis, G.G., Seismic resistance of Type 2 exterior beam - column joints reinforced with inclined bars, $A C I$ Structural Journal, 89(1), pp. 3-12, 1992.

[6] Karayannis, C.G., Chalioris, C.E. \& Sideris, K.K., Effectiveness of RC beam - column connection repair using epoxy resin injections. Journal of Earthquake Engineering, 2(2), pp. 217-240, 1998.

[7] Bakir, P.G., Seismic resistance and mechanical behaviour of exterior beam - column joints with crossed inclined bars. Journal of Structural Engineering and Mechanics, 16(4), pp. 493-517, 2003. 
[8] Tsonos, A.G., Improvement of the earthquake resistance of R/C beam column joints under the influence of P- $\Delta$ effect and axial force variations using inclined bars, Journal of Structural Engineering and Mechanics, 18(4), pp. 389-410, 2004.

[9] ACI Committee 318. Building code requirements for structural concrete (ACI 318-02) and commentary (ACI 318R-02). American Concrete Institute, Farmington Hills, Mich., 2002.

[10] ACI-ASCE Committee 352. Recommendations for design of beamcolumn connections in monolithic reinforced concrete structures (ACI 352R-02). American Concrete Institute, Farmington Hills, Mich., 2002. 